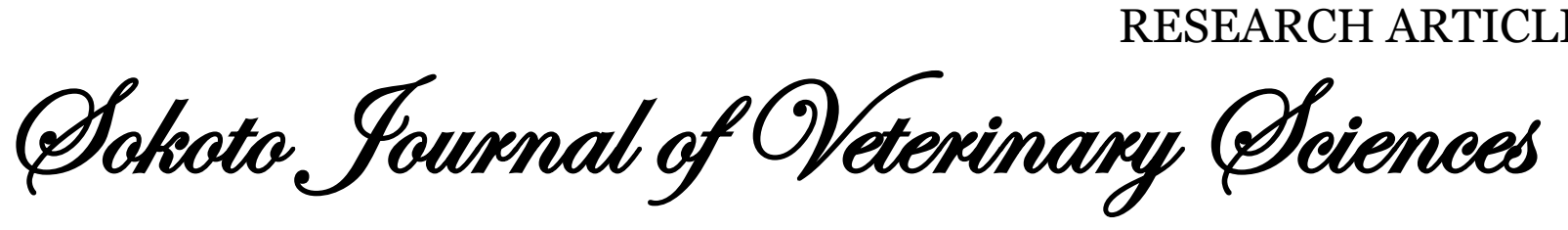

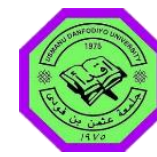 \\ (P-ISSN 1595-093X: E-ISSN 2315-6201) \\ http://dx.doi.org/10.4314/sokjvs.v19i4.2
}

Wungak et al. /Sokoto Journal of Veterinary Sciences, 19(4): 160-165.

\section{Detection of antibodies to H5 and H9 subtypes of influenza viruses in wild birds in Zaria, Nigeria}

\author{
YS Wungak ${ }^{1}$, O Orakpoghenor ${ }^{2}$, I Bitrus ${ }^{3 *}$, KA Olawuyi ${ }^{3}$, OH Osemeke ${ }^{4}$, HG \\ Ularamu $^{1}$, I Shittu ${ }^{3} \&$ CA Meseko ${ }^{3}$ \\ 1. FMD Division, National Veterinary Research Institute, PMB 01 Vom, Plateau State, Nigeria \\ 2. Faculty of Veterinary Medicine, Ahmadu Bello University, Zaria, Nigeria \\ 3. Regional Laboratory for Animal Influenza and other Transboundary Animal Diseases, National Veterinary \\ Research Institute, PMB 01 Vom, Plateau State, Nigeria \\ 4. Viral Research Division, National Veterinary Research Institute, PMB 01 Vom, Plateau State, Nigeria
}

*Correspondence: Tel.: +2347039085893; E-mail: usfilmalgwi@yahoo.com

\begin{abstract}
Copyright: (C) 2021
Wungak et al. This is an open-access article published under the terms of the Creative Commons Attribution License which permits unrestricted use, distribution, and reproduction in any medium, provided the original author and source are credited.
\end{abstract}

Publication History: Received: 11-03-2021 Revised: 27-05-2021

Accepted: 14-06-2021

\section{Abstract}

Avian influenza has impacted negatively on poultry production in Nigeria. The aim of this study was to determine the status of avian influenza virus (AIV) antibodies in wild birds to provide early warning of an outbreak. One hundred and forty-six sera from five different species of wild birds were tested for antibodies to avian influenza A viruses ( $\mathrm{H} 5$ and $\mathrm{H} 9$ ) using enzyme linked immunosorbent assay and haemagglutination inhibition ( $\mathrm{HI}$ ) tests. An overall seroprevalence of $3.4 \%(5 / 146)$ was recorded in the study area. Seroprevalence of $6.67 \%(2 / 30)$ was recorded in speckled pigeons (Columba guinea) and Village weavers (Ploceus cucullatus) respectively and $3.33 \%(1 / 30)$ in Cattle egrets (Bubulcus ibis). No antibodies were detected in laughing doves (Spilolepia senegalensis) and African silver bill (Euodice cantans). The serological detection of AIV subtypes $\mathrm{H} 5$ and $\mathrm{H} 9$ by $\mathrm{HI}$ showed the exposure of these birds to the two subtypes. The result from this study indicates evidence of the presence of $\mathrm{H} 5$ and $\mathrm{H} 9$ Al viruses in wild birds in Zaria, Kaduna State. Therefore, comprehensive surveillance of influenza A involving wild birds' population and $\mathrm{H} 5$ as well as $\mathrm{H} 9$ subtype is recommended. This is necessary in order to know the actual status of these strains in the poultry population in Nigeria in view of their zoonotic and economic importance.

Keywords: Avian Influenza, Antibodies, H5, H9, Nigeria, Seroprevalence, Wild birds

\section{Introduction}

Avian Influenza A viruses belong to the Orthomyxoviridae family, and have a segmented, negative-sense RNA genome. The virus is usually characterized using the combination of their surface proteins; haemagglutinin (HA) and neuraminidase (NA); as a result, a variety of subtypes have been 
identified; for example, H5N1, H5N6, or H9N2 (Peacock et al., 2019a; Sulaiman et al., 2021). Wild aquatic birds are the main reservoir of avian influenza; at least 16 of the 18 haemagglutinin (HA) subtypes (H1-H16) and 9 of the known neuraminidase (NA) subtypes (N1-N9) have been identified in the avian species (Webster et al., 1992; Maclachlan \& Duboyi, 2010). Avian influenza is one of the most important zoonotic diseases that affect poultry, wildlife and human health globally (Peiris et al., 2007; Bahl et al., 2016) usually with pandemic potential. Historically, outbreaks of highly pathogenic avian influenza (HPAI) H5N1, that occurred in China in 1996 and subsequently spread across the world thereafter, have led to tremendous economic losses in the poultry industry as well as loses in wildlife, and considerable loss of human life (Wikramaratna et al., 2014). Also, other pathogenic strains of avian influenza viruses (AIVs) with pandemic potential have emerged such as H7N9 in 2013 and 2015 in South Korea (Chowell et al., 2013; Lycett et al., 2016). However, HPAI H5N1 is now considered endemic in some countries of Southeast Asia, North Africa and Middle East, with its attendant health risk on wildlife and human health (Olsen et al., 2006; Peiris et al., 2007). These threats continue to call for in-depth studies that will unravel the reasons for the emergence, transmission and spread of AIV and ways for its containment. Wild water birds which belong to the orders Anseriformes (including geese, swans and ducks) and to a lesser extent, Charadriiformes (including terns, sandpipers gulls, and plovers) are known to be the natural reservoirs of avian influenza A viruses (Nishiura et al., 2009; Vandegrift et al., 2010; Caron et al., 2017) except subtypes H17N10 and H18N11 which are only found in bats (Wu et al., 2014).

The geographical distributions of these viruses are known to be extended by the migratory representatives of these orders, which serve as important vectors for AIVs (Webster et al., 1992; Verhagen et al., 2015; Lycett et al., 2016). The low prevalence reported in passerine songbirds is an indication of spillover infection through contact with water birds or poultry (Fuller et al., 2010). However, It has also been observed that some peri-domestic species among these, such as house sparrows (Passer domesticus), may play a role in moving AIVs between poultry farms (Vandegrift et al., 2010; Bahl et al., 2016) as well as from other wild birds (Prosser et al., 2013). In Nigeria, the first outbreak of HPAI H5N1 occurred in 2006; the outbreak was attributed to the activities of migratory birds and trade in poultry products as possible sources of introduction and transmission (Ducatez et al., 2006; Lycett et al., 2016). Another wave of the outbreak re-surfaced in 2008 in two northern states of Nigeria. This outbreak caused suspicion of the possible involvement of wild birds in the maintenance and transmission of HPAI H5N1 in Nigeria (Columba-Teru et al., 2012). In 2015, another resurgence of HPAl subtype H5N1 occurred in live bird markets (LBMs) and poultry farms across Nigeria (Meseko \& Oluwayelu, 2019). Serological evidences for H9N2 subtypes exposure have been reported in commercial poultry and humans in Nigeria (Oluwayelu et al., 2020). Although it has been suggested that wild birds play a key role in dynamics and endemicity of HPAI H5NI in Nigeria, there are few studies conducted to ascertain this. This study was conducted to assess the seroprevalence of antibodies against AIV in free-living wild birds and also to determine the status of $\mathrm{H} 5$ and $\mathrm{H} 9$ at the domestic and wildlife interface in Zaria, Kaduna State, Nigeria.

\section{Materials and Methods \\ Study design}

This study was conducted in Zaria, a major city in Kaduna State, Nigeria, with an average elevation of 644 metres above sea level, covering about 300 square kilometres. It has a tropical continental climate with a significant dry season, lasting up to seven months (October - May). A cool period is usually experienced during the dry season, between November and February. Zaria is in the Northern Guinea Savanna, with a diversity of woody shrubs, grasses and short trees. It is located on the geographic coordinates of $11^{\circ} 12^{\prime} \mathrm{N}$ and $7^{\circ} 37^{\prime} \mathrm{E}$. Zaria is a large, heterogeneous city with an approximate population of 1,490,000 (Ehimiyein et al., 2018).

\section{Blood sample collection}

$2-3 \mathrm{ml}$ of blood sample were collected through the wing vein into sterile glass tubes using sterile hypodermic syringes and needle. The samples were from 146 wild birds comprising 30 Laughing doves (Spilolepia senegalensis), 30 Speckled pigeons (Columba guinea), 30 Cattle egrets (Bubulcus ibis), 28 Village weavers (Ploceus cucullatus), and 28 African silver bill (Euodice cantans) (Table 1). The birds were captured using wooden traps set around poultry houses and also purchased from the live bird markets (LBM). They were sampled based on convenient sampling technique; based on available birds at a specific time of capture and purchase. Sera were harvested from each of the blood samples, transferred into sterile cryo-vials, labelled and stored at $-20^{\circ} \mathrm{C}$ until used. 
Enzyme-linked immunosorbent assay

The Antigen AIV Ab ELISA kit (Anigen Animal Genetics Inc., Korea) was used for the screening according to the manufacturer's instructions and as previously conducted by Wungak et al. (2019). The AIV NP antigen coated test plate was prepared. $50 \mu \mathrm{l}$ of controls and sample were added to the wells. About $50 \mu$ of anti AIV antibody-HRP was then added to each well. The plates were then incubated for 30 minutes at $37^{\circ} \mathrm{C}$. After the incubation, plates were washed 6 times. A hundred microliters of substrate solution (ready to use) were then added and plates incubated for 10 minutes at room temperature. 100 $\mu \mathrm{l}$ of stopping solution was then added and the optical density (OD) was measured at $450 \mathrm{~nm}$ with reference wavelength at $620 \mathrm{~nm}$. PI value $=[1-(O D$ sample/mean OD negative)] $\times 100$

\section{Haemagglutination inhibition test}

The haemagglutination inhibition (HI) test was carried out as previously described (Meseko et al., 2012; OIE, 2018) using antigen and antisera specific for $\mathrm{H} 5$ and H9 subtypes. About $0.025 \mathrm{ml}$ PBS were dispensed into each well of a plastic $V$-bottomed microtitre plate and $0.025 \mathrm{ml}$ of serum were later placed into the first well of each plate (A-E). Two-fold dilutions of $0.025 \mathrm{ml}$ volumes of the sera were made across the plate. 4 $\mathrm{HAU}$ virus/antigen in $0.025 \mathrm{ml}$ was added to each well and the plate were left for $30-40 \mathrm{~min}$ at room temperature $\left(20^{\circ} \mathrm{C}\right)$. Later, $0.025 \mathrm{ml}$ of $1 \%(\mathrm{v} / \mathrm{v})$ chicken RBCs was added to each well and mixed gently, the RBCs were allowed to settle to a distinct button for about $40 \mathrm{~min}$ at room temperature $\left(20^{\circ} \mathrm{C}\right)$. The Haemagglutination Inhibition (HI) titre was read from the highest dilution of serum causing complete inhibition of four HAU of antigen. The agglutination was assessed by tilting the plates. Only those wells in which the RBCs streamed at the same rate as the control wells (positive serum, virus/antigen and PBS controls) were considered to show inhibition. The validity of this result was assessed against a negative control. Serum titre greater than or equal to $2^{2}$ or $2 \log 2$ was considered as positive.

\section{Data analysis}

The data were stored in Microsoft Excel ${ }^{\circledR}$ spreadsheet. Descriptive statistics was carried out using Microsoft Excels spreadsheet and proportions were obtained using open Epi Version 2.3.1 Statistical tool (Open-Source Epidemiological Statistics for Public Health calculation). Chi-square $\left(\chi^{2}\right)$ was used to measure the strength of association. $P<0.05$ was considered as significant.

\section{Results}

Out of the 30 sera each from Speckled pigeons, Cattle egrets and Village weavers, 2(6.67\%), 1(3.33\%) and $2(6.67 \%)$ were positive for influenza $A$ virus antibodies respectively using ELISA. No antibody (0\%) was detected in Laughing doves and African silver bills (Table 1). The difference in seropositivity among the wild birds' species was not statistically associated with avian Influenza virus antibodies in the study area ( $p>0.42$ ). Using $\mathrm{HI}$ for subtyping, two of the sera positive by ELISA were positive for serotype $\mathrm{H} 9$, and one was positive for $\mathrm{H} 5$ subtypes using antigen and antisera specific for $\mathrm{H} 5$ and $\mathrm{H} 9$ (Table 2).

\section{Discussion}

Wild birds present a significant risk to poultry biosecurity because they can transmit disease causing agents including AIVs into poultry farms (Waziri et al., 2017). Here, apparently healthy wild birds at this wildlife and domestic birds interface were exposed to AIVs. An overall AIV seroprevalence of $3.42 \%$ (5/146) was recorded. This is similar to the findings of Ameji et al. (2017) who reported AIV seroprevalence of $4 \%$ in wild birds in Kogi State, Nigeria. Waziri et al. (2017)

Table 1: Seroprevalence of AIV antibodies in some wild birds in Zaria, Nigeria using enzyme linked immunosorbent Assay

\begin{tabular}{llllc}
\hline Species of bird & $\begin{array}{l}\text { Number of sera } \\
\text { tested }\end{array}$ & $\begin{array}{l}\text { Number of sera } \\
\text { positive }\end{array}$ & Prevalence & $95 \% \mathrm{Cl}$ \\
\hline Speckled pigeons (Columba guinea) & 30 & 2 & 6.67 & $1.13-20.32$ \\
Cattle egrets (Bubulcus ibis) & 30 & 1 & 3.33 & $0.17-15-$ \\
& & & 6.67 & 15.36 \\
Village weavers (Ploceus cucullatus) & 30 & 2 & 0.00 & $0.0-10.15$ \\
Laughing doves (Spilolepia & 28 & 0 & 0.00 & $0.0-10.15$ \\
senegalensis) & & 0 & 3.42 & $1.27-7.42$ \\
African silver bill (Euodice cantans) & 28 & 5 & & \\
Total & 146 & 52 & & \\
\hline
\end{tabular}

$X=3.9$, df: 4, P-value 0.42 
Table 2: Serological analysis of avian influenza virus subtypes in some wild birds in Zaria, Nigeria using haemagglutination inhibition (HI) test

\begin{tabular}{llll}
\hline Species & No. of sera tested & No. of sera positive for H9 & No. of sera positive for H5 \\
\hline Speckled pigeons (Columba guinea) & 2 & 2 & 0 \\
Cattle egrets (Bubulcus ibis) & 1 & 0 & 0 \\
Village weavers (Ploceus cucullatus) & 2 & 0 & 1 \\
\hline
\end{tabular}

reported seroprevalence rates of $11-15 \%$ for $\mathrm{H} 5$ subtype in wild birds in North-eastern States of Nigeria. Although the bird species surveyed for antibodies against AIVs in this study are not known to play an active role in the maintenance of AIV, they are often viewed as "spill over host" probably being infected from their interaction with poultry or water birds (Fuller et al., 2010). These birds have been suggested to play some roles in the spread of these viruses by movement from one poultry farm to another (Vandegrift et al., 2010; Bahl et al., 2016) or they can transmit the viruses to other wild birds (Prosser et al., 2013). The serological detection of AIV subtype $\mathrm{H} 5$ and $\mathrm{H} 9$ by $\mathrm{HI}$ showed exposure of these bird to the circulating $\mathrm{H} 5$ and $\mathrm{H} 9$ viruses in the environment. It is suggested that H9N2 is endemic especially in the low- and middle-income countries where surveillance is not frequently carried out and H9N2 is not commonly targeted for monitoring or not even investigated at all (Peacock et al., 2019a). The survey of $\mathrm{H} 9$ viruses in other parts of the world have shown hyper-endemicity in poultry birds in both live bird markets and poultry farms (Peacock et al., 2019b; Sulaiman et al., 2021). H9N2 subtype has been documented to have ability to contribute gene segments to other highly pathogenic subtypes of AIV, thereby potentiating their pathogenicity to cause disease in both poultry, other animals and humans (Chen et al., 2014; Huang et al., 2015). Moreover, it has also been reported that $\mathrm{H} 9 \mathrm{~N} 2$ can receive several combinations of genes from other AIVs subtypes thereby increasing its pathogenic and zoonotic potentials (Iqbal et al., 2009; Parvin et al., 2014). Although H9N2 is a low pathogenic AIV, the subtype is found globally, and compared to $\mathrm{H} 5$ and $\mathrm{H} 7$ subtypes, the strain is sometimes neglected during AIV subtypes surveillances (Peacock et al., 2019b). However, current evidence reveals that they could potentially play a significant role in the future emergence of the influenza pandemic, either directly as a H9 AIV subtype virus or as a result of the donation of internal genes to HPAl pandemic subtypes (Peacock et al., 2019b). The finding in this study is similar to that reported by Oluwayelu et al. (2017), who detected H9 influenza virus antibodies in commercial breeders and layers birds in South western Nigerian States.
Similarly, H9 seroprevalence was reported by Okoye et al. (2013) among poultry farm workers and poultry sellers at LBMs in south eastern Nigeria. In conclusion, $\mathrm{H} 5$ and $\mathrm{H} 9$ Al viruses are circulating at the domestic and wild birds interface in Zaria, Kaduna State. Therefore, a comprehensive surveillance of influenza A viruses involving wild birds population as well as $\mathrm{H} 9$ subtype is recommended. This is necessary in order to know the actual status of these strains in commercial poultry in Nigeria due to its zoonotic and economic importance.

\section{Conflict of Interest}

The authors declare that there is no conflict of interest.

\section{References}

Ameji N, Sa'idu L \& Abdu P (2017). Detection of avian influenza antibodies and antigens in poultry and some wild birds in Kogi state, Nigeria. Sokoto Journal of Veterinary Sciences, doi.10.4314/sokjvs.v15i3.9.

Bahl J, Pham TT, Hill NJ, Hussein ITM, Ma EJ, Easterday BC, Halpin RA, Stockwell TB, Wentworth DE, Kayali G, Krauss S, Schultz-Cherry S, Webster RG, Webby RJ, Swartz MD, Smith GJD \& Runstadler JA (2016). Ecosystem interactions underlie the spread of avian influenza A viruses with pandemic potential. PLOS doi.10.1371/journal.ppat.1005620.

Caron A, Cappelle J \& Gaidet N (2017). Challenging the conceptual framework of maintenance hosts for influenza A viruses in wild birds. Journal of Applied Ecology, 54(3): 681-690).

Chen $\mathrm{H}$, Yuan H, Gao R, Zhang J, Wang D, Xiong Y, Fan G, Yang F, Li X, Zhou J, Zou S, Yang L, Chen T, Dong L, Bo H, Zhao X, Zhang Y, Lan Y, Bai T \& Shu $Y$ (2014). Clinical and epidemiological characteristics of a fatal case of avian influenza A H10N8 virus infection: A descriptive study. The Lancet, 383(9918): 714-721.

Chowell G, Simonsen L, Towers S, Miller MA \& Viboud $C$ (2013). Transmission potential of influenza A/H7N9, February to May 2013, China. BMC Medicine, doi.10.1186/1741-7015-11-214. 
Columba-Teru V, Manu SA, Ahmed GI, Junaidu K, Newman S, Nyager J, Iwar VN, Mshelbwala GM, Joannis T, Maina JA \& Apeverga PT (2012). Situation-based survey of avian influenza viruses in possible "Bridge" species of wild and domestic birds in Nigeria. Influenza Research and Treatment, doi.10.1155/2012/567601.

Ducatez MF, Olinger CM, Owoade AA, De Landtsheer S, Ammerlaan W, Niesters HGM, Osterhaus ADME, Fouchier RAM \& Muller CP (2006). Avian Flu: Multiple introductions of $\mathrm{H} 5 \mathrm{~N} 1$ in Nigeria. Nature, doi.10.1038/442037a

Ehimiyein AM, Maishanu DD \& Ehimiyein IO (2018). Prevalence of gastrointestinal and haemoparasites in hunting dogs in Zaria, Nigeria. Sokoto Journal of Veterinary Sciences, 6(3): 55-60.

Fuller TL, Saatchi SS, Curd EE, Toffelmier E, Thomassen HA, Buermann W, DeSante DF, Nott MP, Saracco JF, Ralph CJ, Alexander JD, Pollinger JP \& Smith TB (2010). Mapping the risk of avian influenza in wild birds in the US. BMC Infectious Diseases, doi.10.1186/14712334-10-187.

Huang $Y$, Li X, Zhang H, Chen B, Jiang Y, Yang L, Zhu, W, Hu S, Zhou S, Tang Y, Xiang X, Li F, Li W \& Gao L (2015). Human infection with an avian influenza $A$ (H9N2) virus in the middle region of China. Journal of Medical Virology, 87(10): 1641-1648.

Iqbal M, Yaqub T, Reddy K \& McCauley JW (2009). Novel genotypes of H9N2 influenza a viruses isolated from poultry in Pakistan containing NS genes similar to highly pathogenic H7N3 and H5N1 viruses. PLOS ONE, doi.10.1371/journal.pone.0005788

Lycett SJ, Bodewes R, Pohlmann A, Banks J, Bányai K, Boni MF, Bouwstra R, Breed AC, Brown IH, Chen H Dán Á, DeLiberto TJ, Diep N, Gilbert M, Hill S, Ip HS, Ke CW, Kida H, Killian ML \& Kuiken T (2016). Role for migratory wild birds in the global spread of avian influenza H5N8. Science, 354(6309): 213-217.

Maclachlan NJ \& Dubovi EJ (2010). Fenner's Veterinary Virology: Academic press.

Meseko CA \& Oluwayelu DO (2019). Avian influenza. In Transboundary Animal Diseases. Sahelian Africa and Connected Regions, doi.10.1007/978-3-030-25385-1_17.

Meseko C, Cilloni F \& Oladokun A (2012). Serosurvey of antibody to highly pathogenic avian influenza (H5N1) in pigs, north central
Nigeria. Sokoto Journal of Veterinary Sciences, doi.10.4314/sokjvs.v10i2.9.

Nishiura $H$, Hoye $B$, Klaassen $M$, Bauer $S$ \& Heesterbeek $H$ (2009). How to find natural reservoir hosts from endemic prevalence in a multi-host population: A case study of influenza in waterfowl. Epidemics, 1(2): 118128.

OIE (2018). Manual of Diagnostic Tests and Vaccines for Terrestrial Animals. World Organisation for Animal Health,Rome. May Pp 821-841.

Okoye J, Eze D, Krueger, WS, Heil, GL, Friary JA \& Gray GC (2013). Serologic evidence of avian influenza virus infections among Nigerian agricultural workers. Journal of Medical Virology, doi.10.1002/jmv.23520.

Olsen B, Munster, VJ, Wallensten A, Waldenström J, Osterhaus ADME \& Fouchier RAM (2006). Global patterns of influenza A virus in wild birds. Science, 312(5772): 384-388.

Oluwayelu DO Meseko CA, Ayinmode AB, Adebiyi, AI, Lawani MA \& Kakulu FO (2020). Reemergence of highly pathogenic avian influenza H5N1 in Nigeria, 2014-2016: Role of social network and value chain forces in interstate transmission. Virologica Sinica, doi.10.1007/s12250-020-00201-w.

Oluwayelu DO, Omolanwa A, Adebiyi AI \& Aiki-Raji CO (2017). Flock-based surveillance for low pathogenic avian influenza virus in commercial breeders and layers, southwest Nigeria. African Journal of Infectious Diseases, 11(1): 44-49.

Parvin R, Heenemann K, Halami MY, Chowdhury EH, Islam MR \& Vahlenkamp TW (2014). Fullgenome analysis of avian influenza virus H9N2 from Bangladesh reveals internal gene reassortments with two distinct highly pathogenic avian influenza viruses. Archives of Virology, 159(7): 1651-1661.

Peacock TP, James J, Sealy JE \& Iqbal M (2019a). A global perspective on H9N2 avian influenza virus. Viruses, 11(7): 1-28.

Peacock TP, James J, Sealy JE \& Iqbal M (2019b). A global perspective on H9N2 avian influenza virus. Viruses, 11(7): MDPI AG. doi.10.3390/v11070620.

Peiris JSM, De Jong MD \& Guan Y (2007). Avian influenza virus (H5N1): A threat to human health. Clinical Microbiology Reviews, 20(2): 243-267.

Prosser DJ, Hungerford LL, Erwin RM, Ottinger MA, Takekaw JY \& Ellis EC (2013). Mapping avian influenza transmission risk at the interface of 
domestic poultry and wild birds. Frontiers in

Public Health, doi.10.3389/fpubh.2013.00028.

Sulaiman L, Shittu I, Fusaro, A, Inuwa B, Zecchin B, Gado, D, Schivo A, Bianco A, Laleye A, Gobbo $\mathrm{F}$, Columba V, Tony J, Isabella $\mathrm{M}$ \& Clement $M$ (2021). Live bird markets in Nigeria: A potential reservoir for H9N2 Avian Influenza Viruses. Viruses, doi.10.3390/v13081445.

Vandegrift KJ, Sokolow SH, Daszak P \& Kilpatrick AM (2010). Ecology of avian influenza viruses in a changing world. Annals of the New York Academy of Sciences, doi.10.1111/j.17496632.2010.05451.x.

Verhagen JH, van der Jeugd HP, Nolet BA, Slaterus R, Kharitonov SP, de Vries PP, Vuong O, Majoor F, Kuiken T \& Fouchier RA (2015). Wild bird surveillance around outbreaks of highly pathogenic avian influenza $A(H 5 N 8)$ virus in the Netherlands, 2014, within the context of global flyways. Eurosurveillance, 20(12): 2132

Waziri MI, Abdu PA, Sa L \& Bello M (2017). Seroepidemiology and assessment of risk factors for the spread of avian influenza in birds in two Nigerian states. Veterinary Medicine and Science, 3(4):227-238.

Webster RG, Bean, WJ, Gorman OT, Chambers TM \& Kawaoka Y (1992). Evolution and ecology of influenza A viruses. Microbiological Reviews, 56(1):152-179.

Wikramaratna PS, Pybus OG \& Gupta S (2014). Contact between bird species of different lifespans can promote the emergence of highly pathogenic avian influenza strains. Proceedings of the National Academy of Sciences of the United States of America, 111(29): 10767-10772.

Wungak YS, Lekko YM, Uwakwe EK and Ularamu HG (2019). Detection of antibody to avian influenza virus $A$ in a free-range pig in Taraba State, Nigeria. Vom Journal of Veterinary Science, 14(1): 31-35.

Wu H, Peng X, Xu L, Jin C, Cheng L, Lu X, Xie T, Yao H $\& W u N(2014)$. Novel reassortant influenza A (H5N8) viruses in domestic ducks, eastern China. Emerging Infectious Diseases, 20(8). doi.10.3201/eid2008.140339 